\title{
Vitamin D level in Patients with Prediabetes
}

\section{Prediyabetli Hastalarda D Vitamini Düzeyi}

\author{
Mehmet Gültekin ${ }^{1}$, Nilüfer Özdemir Kutbay² , Ece Onur ${ }^{3}$, Zeliha Hekimsoy $^{2}$ \\ ${ }^{1}$ Celal Bayar University Faculty of Medicine, Internal Medicine, Manisa, Turkey \\ ${ }^{2}$ Celal Bayar University Faculty of Medicine, Division of Endocrinology and Metabolism, Manisa, Turkey \\ ${ }^{3}$ Celal Bayar University Faculty of Medicine, Medical Biochemistry Department, Manisa, Turkey \\ e-mail: mehmet.gultekin3@saglik.gov.tr,nozdemirkutbay@hotmail.com, ece.onur@cbu.edu.tr, \\ zhekimsoy@hotmail.com \\ ORCID: 0000-0003-0184-0047 \\ ORCID: 0000-0002-0719-988X \\ ORCID: 0000-0002-0805-6346 \\ ORCID: 0000-0002-6003-0485 \\ *Sorumlu yazar/ Corresponding Author: Nilüfer Ozdemir Kutbay
}

Gönderim Tarihi / Received: 19.05.2020

Kabul Tarihi / Accepted: 23.11.2020

DOI: $10.34087 /$ cbusbed.797240

$\ddot{\mathrm{O} z}$

Giriş ve Amaç: D vitamini eksikliği; glukoz intoleransı, diabetes mellitus ve metabolik sendroma neden olmaktadır. Literatürde, D vitamini düzeyleri ve prediyabet arasındaki ilişkiyi gösteren veriler çelişkilidir. Bu çalışmada amacımız, prediyabetik hastalarda serum 25-hidroksivitamin D düzeyini değerlendirmek ve D vitamini eksikliğinin veya yetersizliğinin prediyabet gelişimi için bir faktör olup olmadığını belirlemektir.

Gereç ve Yöntemler: Çalışmamıza, 85'i izole Bozulmuş Açlık Glukozu (BAG), 50'si izole Bozulmuş Glukoz Toleransı (BGT) ve 85'i kombine BAG ve BGT olan ve 80'i sağlıklı (benzer yaş, cinsiyet ve VKİ olan) olmak üzere toplam 220 hasta dahil edilmiştir.

Bulgular: BGT ve kombine BAG + BGT tanısı konulan hasta grubu ile kontrol grubu arasındaki ortalama D vitamini düzeyi istatistiksel olarak anlamlı derecede farklıydı (BGT: $11.69 \pm 6.48 \mathrm{ng} / \mathrm{ml}$ karşı kontrol grubu: $16.63 \pm 9.78 \mathrm{ng}$ / ml, p <0.007, BAG + BGT: $13.22 \pm 7.24$ ng / ml karşı kontrol grubu $16.63 \pm 9.78$ ng / ml, p <0.047). Düşük 25hidroksi D vitamini düzeyi, daha yüksek BGT riski ile ilişkili bulunmuştur (OR 2.57, \% 95 GA 1.01-6.53, $\mathrm{p}=0.043$ ). 25-hidroksivitamin D düzeyi kontrol grubunda ve BAG grubunda benzerdi ve istatiksel olarak anlamlı bir fark gözlenmedi (13.90 $\pm 8.89 \mathrm{ng} / \mathrm{ml}$ karşı kontrol grubu $16.63 \pm 9.78 \mathrm{ng} / \mathrm{ml}, \mathrm{p}<0.158)$. Ayrıca BAG, BGT ve BAG + BGT grupları arasında da anlamlı bir fark gözlenmemiştir.

Sonuç: Bu çalışmada D vitamini yetersizliğinin ve eksikliğinin BAG, BGT ve kombine BAG ve BGT riskini arttırdığ 1 gözlenmiştir. Ancak, bu risk, D vitamini eksikliğinde sadece bozulmuş glukoz toleransında önemlidir.

Anahtar kelimeler: D Vitamini, Glukoz intoleransı, Prediyabet.

\section{Abstract}

Objective: Vitamin D deficiency may cause glucose intolerance, diabetes mellitus, and metabolic syndrome. However, there are conflicting data the relationship between vitamin D levels and prediabetes in the literature. Our aim in this study is to evaluate serum 25-hydroxyvitamin D levels in prediabetic patients and to determine if vitamin $\mathrm{D}$ deficiency or insufficiency is a factor for developing prediabetes.

Materials and Methods: Our study included a total of 220 patients, including 85 with isolated Impaired Fasting Glucose (IFG), 50 with isolated Impaired Glucose Tolerance (IGT), and 85 with combined IFG and IGT, and 80 healthy normoglycemic individuals similar in age, gender and BMI.

Results: The mean vitamin D levels between the patient group diagnosed as IGT and IFG+IGT and the control group were statistically significantly different (IGT: $11.69 \pm 6.48 \mathrm{ng} / \mathrm{ml}$ vs. control group: $16.63 \pm 9.78 \mathrm{ng} / \mathrm{ml}, \mathrm{p}<0.007$, IFG+IGT: $13.22 \pm 7.24 \mathrm{ng} / \mathrm{ml}$ vs. control group: $16.63 \pm 9.78 \mathrm{ng} / \mathrm{ml}, \mathrm{p}<0.047$, respectively). Lower 25 -hydroxy vitamin D levels were associated with a higher risk of IGT (OR 2.57, 95\% CI 1.01-6.53, p=0.043). 25-hydroxyvitamin D levels were similar in the control and IFG groups. No significant difference was observed between the IFG and the 
control group $(13.90 \pm 8.89 \mathrm{ng} / \mathrm{ml}$ vs. the control group: $16.63 \pm 9.78 \mathrm{ng} / \mathrm{ml}, \mathrm{p}<0.158)$. Moreover, no significant difference was observed between the IFG, IGT, and IFG+IGT groups, either.

Conclusion: In this study, it was observed that vitamin D insufficiency and deficiency increased the risk of IFG, IGT and combined IFG and IGT. However, this risk was significant only in impaired glucose tolerance in vitamin D deficiency.

Keywords: Glucose intolerance, Prediabetes, Vitamin D.

\section{Introduction}

Prediabetes is a condition defined as the blood glucose concentration level higher than normal but lower than the threshold level of diabetes. This condition comprises a high risk for the development of diabetes. It is associated with an impaired $\beta$-cell function prior to insulin resistance and alterations in the glucose level [1]. The risk of development of cardiovascular morbidity and mortality in patients with prediabetes is increased as in patients with type 2 diabetes. Therefore, prediabetes should be diagnosed early and treated [2]. Almost 25\% of patients with this condition have type 2 diabetes in the future, and this rate is predicted to be even higher among elderly patients [3].

In the literature, studies on type 2 diabetes and vitamin D have reported conflicting results. Studies are suggesting a relationship between vitamin $\mathrm{D}$, type 2 diabetes and metabolic syndrome [4,5,6], and that vitamin D deficiency is a significant risk factor in the development of prediabetes and type 2 diabetes, and that a sufficient level of vitamin D prevents the development of prediabetes and type 2 diabetes [7,8,9,10]. However, other studies are suggesting that vitamin D supplementation has no positive effect on glycemic control in healthy individuals $[11,12,13]$. Therefore, we aimed to evaluate serum 25-hydroxyvitamin D levels in prediabetic patients and to conclude if vitamin D deficiency or insufficiency is a factor for developing prediabetes.

\section{Materials ve Methods}

Our study included a total of 220 patients; 85 with isolated IFG, 50 with isolated IGT, and 85 with combined IFG and IGT, who were diagnosed upon admission to the Department of Internal Medicine and Endocrinology and Metabolism in Celal Bayar University Medical Faculty and 80 healthy normoglycemic individuals similar in age, gender and BMI. The healthy control group included individuals who had a 'normal' $75 \mathrm{~g}$ oral glucose tolerance test (OGTT) result. According to the World Health Organization (WHO), impaired fasting glucose (IFG) is defined as fasting plasma glucose (FPG) of 100$126 \mathrm{mg} / \mathrm{dl}$ (in the absence of IGT), and IGT is defined as post-load plasma glucose of 140-200 mg/dl based on 2-h oral glucose tolerance test (OGTT) or a combination of both [1]. Informed consent was obtained from each of the participants. The study was approved by the Ethics Committee of Celal Bayar University, Faculty of Medicine (25.01.2012 Ethical Approval Number: 55).

The patients with the following exclusion criteria that may affect the metabolic parameters were not included in the study: Type 1 and 2 diabetes, Presence of a disease that may affect the level of vitamin D, history of any medication that may affect the level of vitamin D, Body mass index of $\geq 30 \mathrm{~kg} / \mathrm{m} 2$.

Detailed anamneses of the patients were obtained, and physical examinations were performed. The data regarding the height, weight, age, waist circumference, and body mass index (BMI) $(\mathrm{kg} / \mathrm{m} 2)$ were calculated and recorded.

25-hydroxy vitamin D, calcium, phosphorus, albumin, and parathyroid hormone (PTH) levels were studied in the blood samples, taken from both groups and stored at $-80{ }^{\circ} \mathrm{C}$.

25(OH)D levels were measured by HPLC (ThermoFinnigan, Waltham, USA) using Vitamin D3 ClinRep HPLC kits (RECIPE Chemicals+Instruments GmbH, Munich, Germany).

According to the previously published 25-hydroxy vitamin D level evaluation criteria, a level of $>30 \mathrm{ng} / \mathrm{ml}$ was categorized as normal, $20-30 \mathrm{ng} / \mathrm{ml}$ as vitamin D insufficient, and $<20 \mathrm{ng} / \mathrm{ml}$ as vitamin D deficient [15]. Statistical Analysis

All statistical analyses were performed using the "SPSS 15.0" software. The differences between the sociodemographic characteristics, anthropometric measurements, and laboratory parameters observed in the impaired fasting glucose, impaired glucose tolerance, combined impairment of fasting glucose and glucose tolerance, and the control groups were analyzed using the Chi-square, Anova and the Post-hoc Tukey tests. The differences between the independent variables and the mean concentrations of the laboratory parameters were analyzed using the Anova test. The relationship between $25-\mathrm{OH}$ vitamin $\mathrm{D}$ and parathyroid hormone, the calcium levels, BMI, height, weight, age, and waist circumference parameters were analyzed using the Pearson correlation test. Statistical significance was accepted as $p<0.05$.

\section{Results}

The mean demographic and anthropometric parameters of the patient and the control groups are presented in Table 1. No difference was observed between the study and the control groups with regard to age, weight, and height.

The mean values of the laboratory parameters of the patient and control groups are given in Table 2. The 25hydroxy vitamin D level was found to be $16.63 \mathrm{ng} / \mathrm{ml}$ in the control group, whereas it was determined as 13.90 $\mathrm{ng} / \mathrm{ml}, 11.69 \mathrm{ng} / \mathrm{ml}$, and $13.22 \mathrm{ng} / \mathrm{ml}$ in the IFG, IGT and the combined IFG+IGT groups, respectively.

The odds ratios (OR) and the $95 \%$ confidence intervals (CI) of the study and control groups are presented in Table 3. 
Table 1. The mean demographic and anthropometric parameters of the IFG, IGT, IFG+IGT, and control groups

\begin{tabular}{|c|c|c|c|c|c|c|}
\hline Parameters & $\begin{array}{c}\text { IFG } \\
\text { Group } 1 \\
\text { n=85 } \\
\text { (a) } \\
\text { Mean } \\
\pm \text { SD }\end{array}$ & $\begin{array}{c}\text { IGT } \\
\text { Group } 2 \\
\text { n=50 } \\
\text { (b) } \\
\text { Mean } \\
\pm \text { SD }\end{array}$ & $\begin{array}{c}\text { IFG+IGT } \\
\text { Group } 3 \\
\text { n=85 } \\
\text { (c) } \\
\text { Mean } \\
\pm \text { SD }\end{array}$ & $\begin{array}{c}\text { Control } \\
\text { Group } 4 \\
\text { n=80 } \\
\text { (d) } \\
\text { Mean } \\
\pm \text { SD }\end{array}$ & p* & $\begin{array}{l}\text { Statistical } \\
\text { ranking*** }\end{array}$ \\
\hline Age (year) & $49.69 \pm 10.03$ & $50.92 \pm 15.31$ & $49.37 \pm 9.99$ & $46.33 \pm 10.51$ & 0.096 & $\mathrm{a}=\mathrm{b}=\mathrm{c}=\mathrm{d}$ \\
\hline Height (cm) & $166.54 \pm 5.91$ & $166.88 \pm 6.23$ & $165.60 \pm 5.84$ & $167.05 \pm 6.57$ & 0.448 & $\mathrm{a}=\mathrm{b}=\mathrm{c}=\mathrm{d}$ \\
\hline Weight (kg) & $73.67 \pm 7.22$ & $72.50 \pm 6.80$ & $71.81 \pm 6.78$ & $71.31 \pm 7.59$ & 0.167 & $\mathrm{a}=\mathrm{b}=\mathrm{c}=\mathrm{d}$ \\
\hline BMI $\left(\mathrm{kg} / \mathrm{m}^{2}\right)$ & $26.54 \pm 2.09$ & $26.04 \pm 2.17$ & $26.18 \pm 2.056$ & $25.55 \pm 2.36$ & 0.035 & $\mathrm{~d}<\mathrm{a}=\mathrm{b}=\mathrm{c}$ \\
\hline $\begin{array}{c}\text { Waist } \\
\text { circumferenc } \\
\text { e (cm) }\end{array}$ & $85.10 \pm 6.25$ & $84.32 \pm 8.02$ & $82.69 \pm 5.79$ & $80.92 \pm 7.76$ & 0.001 & $\mathrm{~d}<\mathrm{a}=\mathrm{b}=\mathrm{c}$ \\
\hline
\end{tabular}

*Anova tests, ${ }^{*}$ The Post-hoc Tukey tests

Table 2. The mean values of the laboratory parameters of the IFG, IGT, IFG+IGT, and control groups

\begin{tabular}{|c|c|c|c|c|c|c|}
\hline \multirow[t]{2}{*}{ Parameters } & $\begin{array}{c}\text { IFG } \\
\text { Group } 1 \\
\text { (a) }\end{array}$ & $\begin{array}{c}\text { IGT } \\
\text { Group } 2 \\
\text { (b) }\end{array}$ & $\begin{array}{c}\text { IFG+IGT } \\
\text { Group } 3 \\
\text { (c) }\end{array}$ & $\begin{array}{c}\text { Control } \\
\text { Group } 4 \\
\text { (d) }\end{array}$ & \multirow[t]{2}{*}{$\mathrm{p}^{*}$} & \multirow{2}{*}{$\begin{array}{l}\text { Statistical } \\
\text { ranking*** }\end{array}$} \\
\hline & Mean \pm SD & Mean \pm SD & Mean \pm SD & Mean \pm SD & & \\
\hline $\begin{array}{l}\text { 25(OH) Vitamin } \\
\text { D }(\mathrm{ng} / \mathrm{ml})\end{array}$ & $13.90 \pm 8.89$ & $11.69 \pm 6.48$ & $13.22 \pm 7.24$ & $16.63 \pm 9.78$ & 0.007 & $\begin{array}{c}\mathbf{d}>\mathbf{b}=\mathbf{c} \\
\text { and } \\
\mathbf{d}=\mathbf{a}\end{array}$ \\
\hline Calcium (mg/dl) & $8.53 \pm 0.56$ & $8.25 \pm 0.91$ & $8.46 \pm 0.54$ & $8.15 \pm 0.52$ & 0.000 & $\mathbf{d}<\mathbf{a}=\mathbf{b}=\mathbf{c}$ \\
\hline $\begin{array}{c}\text { Phosphorus } \\
\text { (mg/dl) }\end{array}$ & $3.50 \pm 0.59$ & $3.35 \pm 0.83$ & $3.43 \pm 0.54$ & $3.45 \pm 0.63$ & 0.587 & $\mathrm{a}=\mathrm{b}=\mathrm{c}=\mathrm{d}$ \\
\hline Albumin (g/dl) & $4.17 \pm 0.35$ & $3.92 \pm 0.49$ & $4.20 \pm 0.32$ & $4.01 \pm 0.25$ & 0.000 & $\mathbf{b}<\mathbf{a}=\mathbf{c}=\mathbf{d}$ \\
\hline $\begin{array}{c}\text { Parathyroid } \\
\text { hormone (pg/dl) }\end{array}$ & $59.57 \pm 34.08$ & $62.56 \pm 41.93$ & $48.28 \pm 21.49$ & $52.35 \pm 76.88$ & 0.281 & $\mathrm{a}=\mathrm{b}=\mathrm{c}=\mathrm{d}$ \\
\hline
\end{tabular}

*Anova tests, **The Post-hoc Tukey tests

Table 3. The odds ratios (OR) and the $95 \%$ confidence intervals (CI) of the IFG, IGT, IFG+IGT, and control groups

\begin{tabular}{|c|c|c|c|}
\hline \multirow{2}{*}{$\begin{array}{l}250 H \text { vitamin D } \\
(\mathrm{ng} / \mathrm{ml})\end{array}$} & \multicolumn{3}{|c|}{ OR (\%95 CI) } \\
\hline & Risk of IFG & Risk of IGT & Risk of IFG + IGT \\
\hline$\geq \mathbf{2 0}$ & $\begin{array}{c}1.00 \\
\text { (Reference) }\end{array}$ & $\begin{array}{c}1.00 \\
\text { (Reference) }\end{array}$ & $\begin{array}{c}1.00 \\
\text { (Reference) }\end{array}$ \\
\hline $\begin{array}{c}<20 \text { (Vitamin D } \\
\text { deficiency) }\end{array}$ & $\begin{array}{c}1.68 \\
(0.82-3.45) \\
p=0.149\end{array}$ & $\begin{array}{c}2.57 \\
(1.01-6.53) \\
p=0.043\end{array}$ & $\begin{array}{c}1.97 \\
(0.94-6.53) \\
p=0.068\end{array}$ \\
\hline
\end{tabular}


It was observed that vitamin D deficiency increased the development risk of IFG, IGT, IFG+IGT; however, the increase was statistically significant only in IGT.

\section{Discussion}

Vitamin D was known to be an essential vitamin in musculoskeletal system diseases and mineral metabolism in the past, while its role in the pathogenesis of many diseases has been identified lately. In several studies, vitamin $\mathrm{D}$ has been reported as one of the components of metabolic syndrome, which is a well-known cause of mortality. In addition, vitamin D has become a hormone to be comprehensively investigated after it was found to be related to prediabetes and diabetes. Thus, we aimed to investigate the vitamin $\mathrm{D}$ level in prediabetic patients and the relationship between the vitamin $\mathrm{D}$ level and prediabetes.

Vitamin D level was found to be normal in $5.7 \%$ of the study population $(n=300)$, vitamin $D$ insufficiency was observed in $15.5 \%$ and deficiency in $78.8 \%$. When we compared the results of this study with the sectional study of Hekimsoy et al. conducted in Manisa, where the population included in our study lived [16] $(n=391$, vitamin $\mathrm{D}$ deficiency prevalence: $74.9 \%$ ), the results obtained were similar. The mean vitamin D levels between the patient group diagnosed as IGT and IFG+IGT and the control group were statistically different (IGT $11.69 \pm 6.48 \mathrm{ng} / \mathrm{ml}$ vs. control group $16.63 \pm 9.78 \mathrm{ng} / \mathrm{ml}, \mathrm{p}<0.007$; IFG + IGT $13.22 \pm 7.24 \mathrm{ng} / \mathrm{ml}$ vs. control group $16.63 \pm 9.78 \mathrm{ng} / \mathrm{ml}, \quad \mathrm{p}<0.047$, respectively). No statistically significant difference was observed between the IFG and the control group (IFG $13.90 \pm 8.89 \mathrm{ng} / \mathrm{ml}$ vs. the control group $16.63 \pm 9.78$ $\mathrm{ng} / \mathrm{ml}, \mathrm{p}<0.158)$. No statistically significant difference was observed between the IFG, IGT, and IFG+IGT groups. In our study, the $25-\mathrm{OH}$ vitamin D levels were found to be low in both healthy individuals and prediabetic patients. The low $25-\mathrm{OH}$ vitamin $\mathrm{D}$ level observed in all groups was in line with the result of the previous study conducted in our region [15].

In the study of Pittas et al. on women, the vitamin D levels were found to be lower in patients with new-onset type 2 diabetes $(n=608)$ compared to those in the control group $(n=559)$. After multivariate analysis, the odds ratio for incident diabetes in the top versus the bottom quartile for 25-OHD concentration was 0.52 (95\% CI $0.33-0.83$; $\mathrm{P}$ for trend $=0.008)$ [16]. In our study, we also found the risk of developing IGT to be 2.57-fold higher among patients with vitamin D deficiency (95\% CI, 1.01-6.53, $\mathrm{p}<0.043)$. The role of vitamin D in pancreatic beta cell function can be achieved through the binding of circulating 1,25-dihydroxyvitamin $\mathrm{D}$ to the beta cell vitamin D receptor. Vitamin D can directly increase insulin sensitivity by stimulating the expression of insulin receptors and / or activating the peroxisome proliferator-activated receptor, a factor involved in the regulation of fatty acid metabolism in skeletal muscle and adipose tissue. Vitamin D may also affect insulin secretion and sensitivity indirectly through its role in regulating extracellular calcium concentration and flow in beta cell cell membranes and peripheral insulin target tissues [11]. These mechanisms may help us explain why impaired glucose tolerance associated with insulin resistance in peripheral tissues increases in vitamin D deficiency.

In another study conducted in Australia, a total of 5200 non-diabetic cases were followed-up for 5 years, and it was found that vitamin D levels were lower in 199 patients who developed diabetes compared to those who did not [17]. An 11-year-follow up study in Norway demonstrated that lower baseline serum 25(OH)D concentrations were associated with a higher risk of Type $2 \mathrm{DM}$ in a prospective population-based study; however, this finding was no longer significant after adjustment for BMI [18].

In a prospective study, Pittas et al. followed-up 83779 women with no history of diabetes for 20 years, and found that a combined daily intake of $>1,200 \mathrm{mg}$ calcium and $>800$ IU vitamin D was associated with a $33 \%$ lower risk of type 2 diabetes with the relative risk of 0.67 (0.490.90 ) compared with an intake of $<600 \mathrm{mg}$ and $400 \mathrm{IU}$ calcium and vitamin $\mathrm{D}$, respectively [19]. In another study of Pittas et al. conducted on a total of 314 participants, including 92 patients with prediabetes and 222 individuals with normal glucose metabolism, fasting plasma glucose, and insulin resistance were evaluated by administering either $500 \mathrm{mg}$ calcium and $700 \mathrm{IU}$ vitamin D3 or placebo daily for 3 years. Placebo was administered to 114 of 222 cases with normal glucose metabolism, $500 \mathrm{mg}$ calcium and $700 \mathrm{IU}$ vitamin D3 daily were administered to 108 , and 47 of 92 cases with prediabetes were administered placebo and 45 were administered $500 \mathrm{mg}$ calcium and $700 \mathrm{IU}$ vitamin D3 daily. In the group with normal glucose metabolism, no difference was observed between the two treatment arms with regard to fasting plasma glucose and insulin sensitivity. In the IFG group, those who took combined calcium-vitamin D supplements had a lower rise in FPG at 3 years compared with those on placebo $(0.02 \mathrm{mmol} / \mathrm{l}$ $(0.4 \mathrm{mg} / \mathrm{dl})$ vs. $0.34 \mathrm{mmol} / 1(6.1 \mathrm{mg} / \mathrm{dl})$, respectively, $\mathrm{P}=0.042)$ and a lower increase in insulin resistance $(0.05$ vs. 0.91, $\mathrm{P}=0.031)$. Also, vitamin $\mathrm{D}$ and calcium supplementation were found to improve glycemic levels in patients with prediabetes [20].

In the study of Nikooyeh et al. 90 diabetic patients were randomly allocated to 3 groups: consuming plain yogurt drink (containing no vitamin D and $150 \mathrm{mg} \mathrm{Ca} / 250 \mathrm{~mL}$ ), vitamin D-fortified yogurt drink (containing $500 \mathrm{IU}$ vitamin $\mathrm{D} 3$ and $150 \mathrm{mg} \mathrm{Ca} / 250 \mathrm{~mL}$ ), or vitamin $\mathrm{D}+$ calcium-fortified yogurt drink (containing 500 IU vitamin D3 and $250 \mathrm{mg} \mathrm{Ca} / 250 \mathrm{~mL}$ ) twice per day for 12 weeks. Glycemic status in type 2 diabetes mellitus patients was found to improve with a daily intake of a vitamin D-fortified yogurt drink, either with or without added calcium [21]. In a Chinese population-based crosssectional study, including 3762 individuals, a low vitamin D level is considerably associated with an increased risk of metabolic syndrome and insulin resistance [22]. 
When the literature was investigated with regard to the relationship between vitamin D deficiency and prediabetes in prediabetic patients, it was observed that Guo et al. had evaluated the relationship between serum 25-hydroxy vitamin D level and glucose metabolism. 25hydroxy vitamin D level was $13.57 \mathrm{ng} / \mathrm{dl}$ in patients with type 2 diabetes $(n=160), 15.65 \mathrm{ng} / \mathrm{dl}$ in those with impaired fasting glucose/impaired glucose tolerance $(\mathrm{n}=178)$ and $23.97 \mathrm{ng} / \mathrm{dl}$ in controls with normal glucose metabolism $(n=180)$. It was demonstrated that the 25 hydroxy vitamin D level was significantly higher in the healthy control group compared to those in the groups with diabetes and prediabetes $(\mathrm{P}<0.05)$ [8]. In our study, the 25 -hydroxy vitamin D level was $16.63 \mathrm{ng} / \mathrm{ml}$ in the control group $(\mathrm{n}=80), 13.90 \mathrm{ng} / \mathrm{ml}$ in the impaired fasting glucose group $(\mathrm{n}=85), 11.69 \mathrm{ng} / \mathrm{ml}$ in the impaired glucose tolerance group $(\mathrm{n}=50)$ and $13.22 \mathrm{ng} / \mathrm{ml}$ in the combined impaired fasting glucose/impaired glucose tolerance group $(\mathrm{n}=85)$, which is similar to the results of the study conducted by Guo et al. [8].

In some studies in the literature, it is seen that there is no relationship between 25OHD3 and prediabetes $[11,12,13]$. In these studies, it was suggested that the small number of people in the sample and vitamin D levels may be effective in the results. Vitamin D receptor polymorphisms may also be effective in this difference $[23,24]$. The low number of patients included in our study and the fact that its relation with vitamin $D$ was not evaluated by calculating the Indices Related to Insulin Release and Resistance in prediabetic patients are the limitations of our study. Both preclinical and clinical studies that will be conducted in the future will help us to better understand the mechanisms underlying the relationship between prediabetes and vitamin D.

\section{Conclusion}

In conclusion, in this study, vitamin D insufficiency and deficiency were observed to increase the risk of impaired fasting glucose $(95 \% \mathrm{CI}, 0.82-3.45, \mathrm{p}=0.149)$, impaired glucose tolerance $(95 \% \mathrm{CI}, 1.01-6.53, \mathrm{p}=0.043)$, and combined impaired fasting glucose and impaired glucose tolerance $(95 \% \mathrm{CI}, 0.94-6.53, \mathrm{p}=0.068)$. However, this risk was statistically significant only in the impaired glucose tolerance in vitamin D deficiency $(95 \%$ CI, 1.01 $6.53, \mathrm{p}=0.043)$. Further comprehensive and prospective studies are essential in order to indicate whether vitamin $\mathrm{D}$ deficiency is an additional risk factor increasing glucose intolerance and to reveal the importance of vitamin $\mathrm{D}$ in the prevention of type 2 diabetes that has already become an epidemic.

\section{References}

1. Tabák, AG, Herder, C, Rathmann, W, Brunner, E.J, Kivimäki, M, Prediabetes: a high-risk state for diabetes development, Lancet, 2012, 379, 2279-2290

2. Petersen, J.L, McGuire, D.K, Impaired glucose tolerance and impaired fasting glucose-a review of diagnosis, clinical implications and management, Diabetes and Vascular Disease Research, 2005, 2 $9-15$.

3. Nathan, D.M, Davidson, M.B, DeFronzo, R.A, Heine, R.J, Henry, R.R, Pratley, R et al., American Diabetes Association, Impaired fasting glucose and impaired glucose tolerance: implications for care, Diabetes Care, 2007, 30, 753-759.
4. Pittas, A.G, Chung, M, Trikalinos, T, Mitri, J, Brendel, M, Patel, K et al., Systematic review: Vitamin D and cardiometabolic outcomes, Annals of Internal Medicine, 2010, 152, 307-314.

5. Zhao, G, Ford, E.S, Li, C, Associations of serum concentrations of 25-hydroxyvitamin D and parathyroid hormone with surrogate markers of insulin resistance among U.S. adults without physiciandiagnosed diabetes: NHANES, 2003-2006, Diabetes Care, 2010, 33, 344-347.

6. Liu, E, Meigs, J.B, Pittas, A.G, Economos, C.D, McKeown, N.M, Booth, S.L et al., Predicted 25-hydroxyvitamin D score and incident type 2 diabetes in the Framingham Offspring Study, The American Journal of Clinical Nutrition, 2010, 91, 1627-1633.

7. Tsur, A, Feldman, B.S, Feldhammer, I, Hoshen, M.B, Leibowitz, G Balicer, R.D, Decreased serum concentrations of 25Hydroxycholecalciferol are associated with increased risk of progression to impaired fasting glucose and diabetes, Diabetes Care, 2013, 36(5), 1361-1367

8. Guo, J, Xiao, Z, Xue, X, Liu, X, Lu, Y, Yin, X et al., 25 Hydroxyvitamin $D$ is closely related with the function of the pancreatic islet $\beta$ cells, Pakistan Journal of Medical Sciences, 2013 , 29(3), 809-813.

9. Shankar, A, Sabanayagam, C, Kalidindi, S., Serum 25Hydroxyvitamin D levels and prediabetes among subjects free of diabetes, Diabetes Care, 2011, 34(5), 1114-1119.

10. Gao, Y, Zheng, T, Ran, X, Ren, y, Chen, T, Zhong, L et al., Vitamin $\mathrm{D}$ and incidence of prediabetes or type 2 diabetes: A four-year followup community-based study, Disease Markers, 2018, 1926308.

11. Pittas, G, Hughes, B, Vitamin D and diabetes, Journal of Steroid Biochemistry \& Molecular Biology, 2010, 121, 425-1429.

12. Giorelli, G.V, Matos, L.N, Saado, A, Soibelman, V.L, Dias, C.B, No association between 25-hydroxyvitamin D levels and prediabetes in Brazilian patients, A cross-sectional study, Sao Paulo Medical Journal, 2015, 133(2), pp.73-77,

13. Modi, K.D, Ahmed, M.I, Chandwani, R, Kumar H., Prevalence of vitamin D deficiency across the spectrum of glucose intolerance, Journal of Diabetes \& Metabolic Disorders, 2015, 14, 54, https://doi.org/10.1186/s40200-015-0179-5.

14. Dusso, A.S, Brown, A.J, Slatopolsky, E, Vitamin D, American Journal of Physiology-Renal Physiology, 2005, 289, 8-28.

15. Hekimsoy, Z, Dinç, G, Kafesçiler, S, Onur, E, Güvenç, Y, Pala, T et al., Vitamin D status among adults in the Aegean region of Turkey, BMC Public Health, 2010, 10, 782.

16. Pittas, A.G, Sun, Q, Manson, J.E, Dawson-Hughes, B, Hu, F.B, Plasma 25-hydroxyvitamin D concentration and risk of incident type 2 diabetes in women, Diabetes Care, 2010, 33, 2021-2023.

17. Gagnon, C, Lu, Z.X, Magliano, D.J, Dunstan, D.W, Shaw, J.E Zimmet, P.Z et al., Serum 25-hydroxyvitamin D, calcium intake, and risk of type 2 diabetes after 5 years: results from a national, population-based prospective study (the Australian Diabetes, Obesity and Lifestyle study), Diabetes Care, 2011, 34, 1133-1138.

8. Grimnes, G, Emaus, N, Joakimsen, R.M, Figenschau, Y, Jenssen, T, Njølstad, I et al., Baseline serum 25-hydroxyvitamin D concentrations in the Tromsø Study 1994-95 and risk of developing type 2 diabetes mellitus during 11 years of follow-up, Diabetic Medicine, 2010, 27, 1107-1115.

19. Pittas, A.G, Dawson-Hughes, B, Li, T, Van Dam, R.M, Willett, W.C Manson, J.E, Hu, F.B., Vitamin D and calcium intake in relation to type 2 diabetes in women, Diabetes Care, 2006, 29, 650-656.

20. Pittas, AG, Harris, S.S, Stark, P.C, Dawson-Hughes, B., The effects of calcium and vitamin D supplementation on blood glucose and markers of inflammation in nondiabetic adults, Diabetes Care, 2007, 30, 980-986.

21. Nikooyeh, B, Neyestani, T.R, Farvid, M, Alavi-Majd, H, Houshiarrad, A, Kalayi, A et al., Daily consumption of vitamin D or vitamin D+calcium fortified yogurt drink improved glycemic control in patients with type 2 diabetes: a randomized clinical trial, The American Journal of Clinical Nutrition, 2011, 93, 764-771.

22. Lu, L, Yu, Z, Pan, A., Plasma 25-hydroxyvitamin D concentration and metabolic syndrome among middle-aged and elderly Chinese individuals, Diabetes Care, 2009, 32(7), 1278-1283.

23. Jia, J, Ding, H, Yang, K, et al., Vitamin D Receptor Genetic Polymorphism Is Significantly Associated with Risk of Type 2 Diabetes Mellitus in Chinese Han Population, Archives of Medical Research, 2015, 46(7), 572-579. 
24. Liao, S, He, J, Li, X, et al., Association between VDR gene polymorphisms and HOMA index for prediabetes in Ningxia, Journal of Hygiene Research, 2016, 45(2), 184-188.

http://edergi.cbu.edu.tr/ojs/index.php/cbusbed isimli yazarın CBU-SBED başlıklı eseri bu Creative Commons Alıntı-Gayriticari4.0 Uluslararası Lisansı ile lisanslanmıştır.

(c) (7) (5) 